\title{
Organophosphorus and Carbamate Insecticides as Substitutes for DDT in Controlling the Tobacco Flea Beetle on Flue-Cured Tobacco*
}

\author{
by W. J. Mistric, Jr., and F. D. Smith \\ Department of Entomology, North Carolina State University, Raleigh, N. C., USA
}

DDT has been the principal insecticide used to control the tobacco flea beetle, Epitrix hirtipennis (Melsheimer), on flue-cured tobacco in North Carolina. The choice of DDT for flea beetle control has been due to a combination of factors, some of the more important being its [1] long residual effectiveness against flea beetles, [2] low phytotoxicity, [3] low cost, [4] low toxicity to the applicator, [5] easy procurement in a variety of formulations, and [6] effectiveness against the tobacco budworm, Heliothis virescens (F.), which sometimes requires treatment at the same time as flea beetles.

Residues of DDT in the mainstream smoke of United States cigarettes have remained below the tolerance limit permitted on leafy vegetables in the United States $(x)$. However, tolerances for insecticides on tobacco proposed by West Germany (1966) (2) indicate that, if these tolerances are enacted, United States tobacco treated with DDT will no longer be acceptable in West Germany. Also, tobacco importers in other countries are concerned about the present levels of DDT residue on United States tobacco. Since the export market for United States tobacco is particularly important, the Entomology Section, Tobacco Workers' Conference (1968) (3) removed DDT from the list of insecticides suggested for the control of insects on field-growing tobacco. Similarly, DDT was subsequently removed from the North Carolina recommendations (4).

This report is an expansion of Dominick's ( 5 to 10 ) studies on the use of insecticidal sprays to control the tobacco flea beetle on flue-cured tobacco in Virginia. It compares the residual effectiveness of [1] DDT, [2] insecticides which may be presently substituted for DDT, and [3] certain experimental insecticides. Such information is important in the selection of current and future replacements for DDT.

\footnotetext{
" Paper no. 2957 of the Journal Series of the North Carolina State University Agricultural Experiment Station, Raleigh.
}

Reprinted from the Journal of Economic Entomology 63 (1970) 509-511.

\section{METHODS AND MATERIALS}

Four field experiments were conducted in North Carolina during 1964-65 to compare the residual effectiveness of insecticidal sprays against the tobacco flea beetle on flue-cured tobacco. The experiments were of randomized block design. Treatments (Table 1 ) were replicated 3 times in Experiment 4 and 4 times in the other experiments. Plots were $I$ row $\times 60 \mathrm{ft}$ in Experiment 4 and 4 rows $\times 60 \mathrm{ft}$ in the other experiments. There were 2 untreated buffer rows between plots in Experiment 4 but none in the other experiments.

At the time of treatment there were about 8 leaves/plant in Experiment 1, 16 in Experiments 3 and 4, and 24 in Experiment 2. In relation to the plant sizes just described, sprays were delivered at 15,23 , and $35 \mathrm{gal} / \mathrm{acre}$ through 2, 3, and $5 \mathrm{D} 3-23 \mathrm{HC}$ nozzles* per row, respectively. A high-clearance self-propelled sprayer operating at 60 psi spray pressure was used in all experiments.

Flea beetle infestations were recorded 3,6 , and 10 days after the sprays were applied. The infestation records were obtained from the single-row plots in Experiment 4 and the 2 middle rows of each plot in the other experiments. Sixteen plants/plot were examined for flea beetles in Experiment 1, 10 plants in Experiments 3 and 4 , and 32 leaves (leaves 11 and 12 on each of 16 plants) in Experiment 2.

Methods outlined by LeClerg et al. (11) were employed in the statistical analysis of the data. Square roots of the numbers of flea beetles were subjected to analysis of variance, and Duncan's multiple range test was applied to the treatment means. Mean values were converted to original units for presentation in Table 1.

\footnotetext{
* Manufactured by Spraying Systems Company, Bellwood, Illinois.
} 
Insecticides and supply sources used in these studies were: aminocarb, azinphosmethyl, and Dasanit ${ }^{\circledR}(O, O$ diethyl $O-[p$-(methylsulfinyl)phenyl] phosphorothioate) -Chemagro; carbanolate-Upjohn; carbaryl-Union Carbide; carbofuran, DDT, and endosulfan-Niagara; diazinon and Supracide ${ }^{\otimes}$ (S-((2-methoxy-5-0xo- $\Delta^{2}-1,3,4-$ thiadiazolin-4-yl)methyl) $\mathrm{O}, \mathrm{O}$-dimethyl phosphorodithioate)-Geigy; dicrotophos, Gardona ${ }^{\otimes}$ (2-chloro-1- (2,4,5-trichlorophenyl) vinyl dimethyl phosphate), and monocrotophos-Shell; dimethoate and malathionAmerican Cyanamid; $\operatorname{Imidan}^{\otimes}(\mathrm{O}, \mathrm{O}$-dimethyl $S$ phthalimidomethyl phosphorodithioate) - Stauffer; MCA-60o (benzo[b]thien-4-yl methylcarbamate) -Mobil; methyl parathion and parathion-Monsanto; naled and phosphamidon-Chevron; and TDE-Allied.

Table 1 Number of adult tobacco flea beetles on flue-cured tobacco plants following spray applications of insecticides Reidsville and Clayton, North Carolina, 1964-65

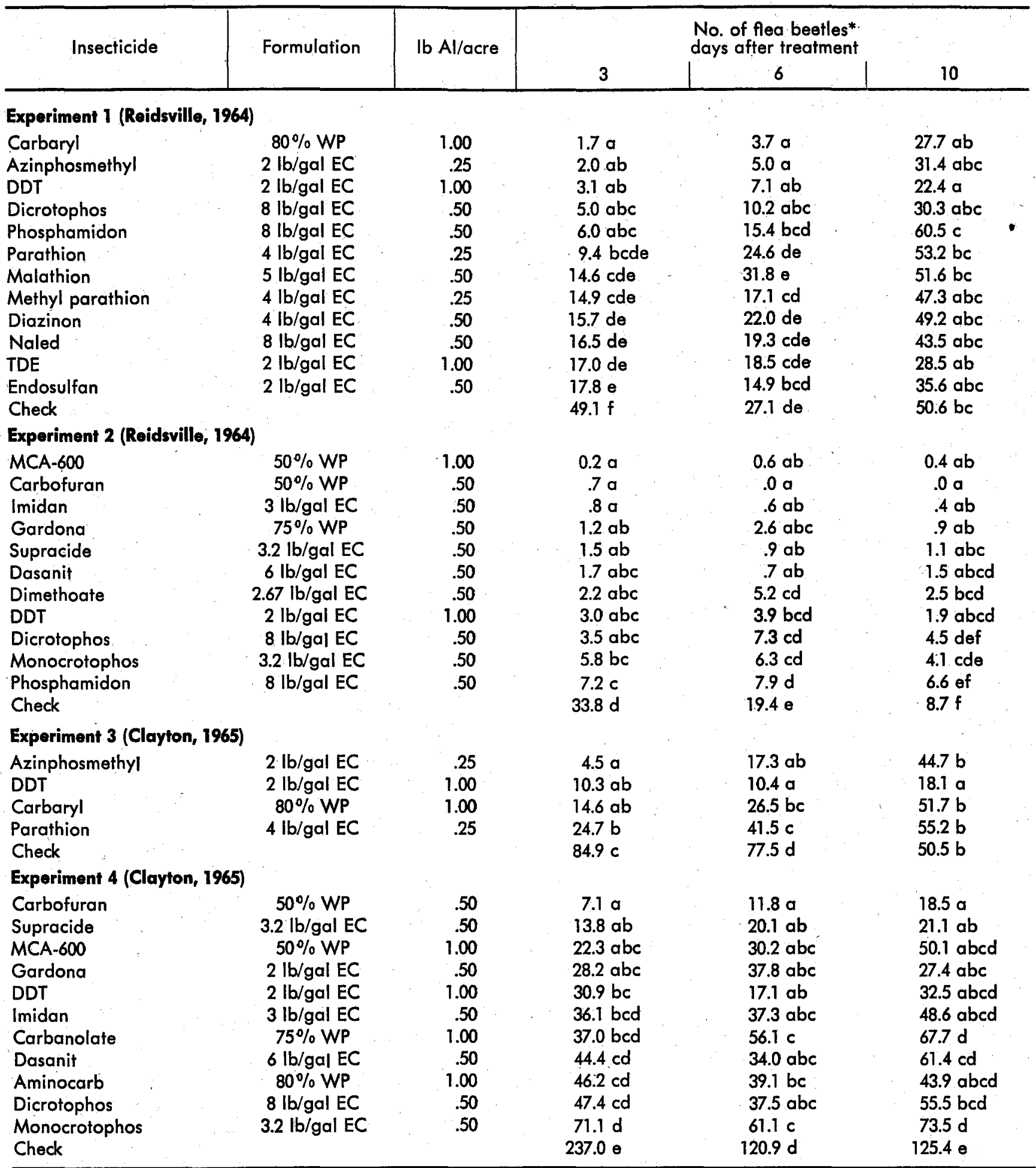

* Per 16 plants in Experiment 1, 32 leaves in Experiment 2, and 10 plants in Experiments 3 and 4. Means followed by a common letter are not significantly different at $5 \%$ level. 


\section{RESULTS}

Little or no variation was observed in the relative performance of most insecticides from one experiment to another. In all experiments DDT reduced significantly the flea beetle infestation 3,6 , and 10 days after application. In only one instance did an insecticide give significantly greater control than DDT, that being carbofuran 3 days after application in Experiment 4. In general, for the number of days indicated, the following treatments provided significant control similar to that obtained with $1 \mathrm{lb} /$ acre of DDT: [1] for 10 days, $0.5 \mathrm{lb}$ of carbofuran, Dasanit, dimethoate, Gardona, Imidan, and Supracide, and $1 \mathrm{lb}$ of aminocarb and MCA-600, [2] for 6 days, $0.25 \mathrm{lb}$ of azinphosmethyl, $0.5 \mathrm{lb}$ of dicrotophos and phosphamidon, and $\mathrm{I} \mathrm{lb}$ of carbaryl, and [3] for 3 days, $0.25 \mathrm{lb}$ of parathion and $1 \mathrm{lb}$ of carbanolate. For 3 days the following treatments provided significant but less control than that obtained with $1 \mathrm{lb}$ of DDT: $0.25 \mathrm{lb}$ of methyl parathion, $0.5 \mathrm{lb}$ of diazinon, endosulfan, malathion, and naled, and $1 \mathrm{lb}$ of TDE. The relative performance of monocrotophos varied considerably from one experiment to another. On the basis of these variable results, monocrotophos did not appear particularly promising for flea beetle control.

\section{DISCUSSION}

Insecticides which provided flea beetle control similar to that obtained with DDT for 10 days were: carbofuran, Dasanit, dimethoate, Gardona, Imidan, aminocarb, MCA600 , and Supracide. All these insecticides are in the experimental stage of development for use on tobacco. Additional research on the control of flea beetles and other tobacco insects with these materials is underway. With respect to insecticides recommended currently for tobacco flea beetle control in North Carolina, azinphosmethyl and carbaryl provided control similar to that of DDT for 6 days, while parathion provided similar control for 3 days. Thus, under conditions of persistent reinfestation, these insecticides should be applied at shorter intervals than DDT was once applied.

Eñdosulfan, malathion, and TDE, which are recommended for the control of other tobacco insects in North Carolina, provided flea beetle control inferior to that of DDT for 3 days and no significant control thereafter. Because of this poor performance, these materials should not be used specifically for flea beetle control. In addition, the use of TDE for flea beetle control would increase residue problems presently associated with the use of this material against other tobacco insects.

\section{SUMMARY}

Field experiments conducted in North Carolina during 1964-65 to compare the residual effectiveness of insecticidal sprays against the tobacco flea beetle, Epitrix hirtipennis (Melsheimer), on flue-cured tobacco showed that, for the number of days indicated after application, the following treatments provided control similar to that obtained with $1 \mathrm{lb} / \mathrm{acre}$ of DDT: [1] for 10 days, $0.5 \mathrm{lb}$ of carbofuran, Dasanit ${ }^{\Theta}$ (o,o-diethyl o-[p-(methylsulfinyl)phenyl]phosphorothioate), dimethoate, Gardona $^{\circledR}$ (2-chloro-1-(2,4,5-trichlorophenyl) vinyl dimethy] phosphate), Imidan ${ }^{\otimes}$ (o,o-dimethyl S-phthalimidomethy] phosphorodithioate), and Supracide ${ }^{\otimes}$ (S-((2-methoxy5-oxo- $\triangle^{2}-1,3,4$-thiadiazolin-4-yl)methyl) o,o-dimethyl phosphorodithioate), and $1 \mathrm{lb}$ of aminocarb and MCA600 (benzo[b]thien-4-yl methylcarbamate), [2] for 6 days, $0.25 \mathrm{lb}$ of azinphosmethyl, $0.5 \mathrm{lb}$ of dicrotophos and phosphamidon, and $1 \mathrm{lb}$ of carbaryl, and [3] for 3 days, $0.25 \mathrm{lb}$ of parathion and $\mathrm{I} \mathrm{lb}$ of carbanolate.

One-fourth $\mathrm{lb}$ of methyl parathion, $0.5 \mathrm{lb}$ of diazinon, endosulfan, malathion, and naled, and $1 \mathrm{lb}$ of TDE provided control inferior to that of $I \mathrm{lb}$ of DDT for 3 days and no significant control thereafter. Variable control was obtained with monocrotophos.

\section{ZUSAMMENFASSUNG}

In den Jahren 1964 und 1965 wurden in North Carolina Feldversuche durchgeführt, die dazu dienen sollten, Reste von versprühten Insektiziden in ihrer Wirksamkeit zur Bekämpfung des Erdflohs, Epitrix hirtipennis (Melsheimer), zu vergleichen. Bei Feldbehandlung des Tabaks (flue-cured) zeigten die nachstehend angeführten Insektixide für die angegebene Dauer eine Wirkung, die mit der des DDT ( $1 \mathrm{lb}$./acre) vergleichbar war: [1] für die Dauer von 10 Tagen, $0,5 \mathrm{lb}$. Carbofuran, Dasanit ${ }^{\circledast}(0,0-$ Diäthyl o-[p-(methylsulfinyl)phenyl] phosphorothioat), Dimethoat, Gardona ${ }^{\otimes}$ (2-Chloro-1-(2,4,5-trichlorophenyl) vinyl dimethyl phosphat), Imidan ${ }^{\otimes}$ (o,oDimethyl 5-phthalimidomethyl phosphorodithioat) und Supracide ${ }^{\otimes}$ (S-((2-methoxy-5-oxo- $\Delta^{2}-1,3,4$-thiadiazolin-4-yl)methyl) 0,0 -dimethyl phosphorodithioat) und $1 \mathrm{lb}$. Aminocarb und MCA-60o (Benzo[b]thien-4-yl methylcarbamat), [2] für die Dauer von 6 Tagen, $0,25 \mathrm{lb}$. Azinphosmethyl, $0,5 \mathrm{lb}$. Dicrotophos und Phosphamidon und $\mathrm{I} \mathrm{lb}$. Carbaryl, und [3] für die Dauer von 3 Tagen, 0,25 lb. Parathion und $1 \mathrm{lb}$. Carbanolat.

Ein viertel lb. Methyl-Parathion, $0,5 \mathrm{lb}$. Diazinon, Endosulfan, Malathion und Naled sowie I lb. TDE erwiesen sich im Vergleich $z u \quad I \mathrm{lb}$. DDT für 3 Tage nach der. Behandlung als weniger wirksam und zeigten später keine insektizide Wirkung mehr. Unterschiedliche Wirkungen ergaben sich nach der Behandlung mit Monocrotophos.

\section{RESUME}

Des insecticides ont été pulvérisés sur du tabac "fluecured « '(séché à air chaud), pour le protéger contre l'altise du tabac, Epitrix hirtipennis (Melsheimer). Ces applications en terrain ont été effectuées en Caroline du Nord au cours des années $1964-65$, pour comparer la rémanence des insecticides après le nombre de jours indiqués: les traitements suivants ont procuré une protection comparable à 1 lb./acre de DDT: [1] pour une durée de 10 jours, $0,5 \mathrm{lb}$. de carbofuran, Dasanit ${ }^{\circledR}$ (o,o-diéthyl o-[p-(méthylsulfinyl) phé- 
nyl] phosphorothioate), de diméthoate, Gardona (2-chloro-1-(2,4,5-trichlorophényl) vinyl diméthyl phosphate), d'Imidan ${ }^{\otimes}$ (0,0- diméthyl S-phtalimidométhyl phosphorodithioate), et de Supracide ${ }^{\circledR}$ (5-(2-méthoxy5-oxo- $\Delta^{2}-1,3,4$-thiadiazoline-4-yl) méthyle) o,o-diméthyl phosphorodithioate), et $1 \mathrm{lb}$. d'aminocarb et de MCA600 (benzo[b] thien-4-yl méthylcarbamate), [2] pour une durée de 6 jours, $0,25 \mathrm{lb}$. d'azinphosméthyle, $0,5 \mathrm{lb}$. de dicrotophos et de phosphamidon, et $1 \mathrm{lb}$. de carbaryl, et [3] pour une durée de 3 jours, $0,25 \mathrm{lb}$. de parathion et $\mathrm{I} \mathrm{lb}$. de carbanolate.

Un quart de $\mathrm{lb}$. de méthyl parathion, $0,5 \mathrm{lb}$. de diazinon, d'endosulfan, de malathion, et de Dibrom (naled), et $I \mathrm{lb}$. de DDD (TDE) ont procuré une protection inférieure à celle $d^{\prime} I l b$. de DDT pour une durée de 3 jours et une protection insuffisante par la suite. Une protection variable a été obtenue avec le monocrotophos.

\section{REFERENCES}

1. Guthrie, F. E., and Bowery, T. G.: Residue Reviews 19 (1967) 31.

2. Verordnung über Pflanzenschutz-, Schädlingsbekämpfungs- und Vorratsschutzmittel in oder auf Lebensmitteln pflanzlicher Herkunft (HöchstmengenVO - Pflanzenschutz -) vom 30. November 1966, Bundesgesetzblatt, Teil I, Z 1997 A, Nr. 53, ausgegeben zu Bonn am 10. 12. 1966, p. 667 .
3. Entomology Section, Tobacco Workers' Conference: Suggestions for the control of tobacco insects for the seasons of 1969 and 1970, 22nd Tobacco Workers' Conference, Asheville, N. C., 1968.

4. Robertson, R. L., Rabb, R. L., and Mistric, W. J., Jr.: Tobacco Insect Control, In: North Carolina Pesticide-Fertilizer Manual, Division of Continuing Education, N. C. State University, Raleigh, 1969, p. 41.

5. Dominick, C. B.: J. Econ. Entomol. 42 (1949) 148.

6. Dominick, C. B.: J. Econ. Entomol. 47 (1954) 346.

7. Dominick, C. B.: J. Econ. Entomol. 49 (1956) 425.

8. Dominick, C. B.: Tobacco Sci. I (1957) 109.

9. Dominick, C. B.: J. Econ. Entomol. 55 (1962) 874.

10. Dominick, C. B.: Tobacco Sci. 9. (1965) 143.

11. LeClerg, E. L., Leonard, W. H., and Clark, A. G.: Field Plot Technique, 2nd ed., Burgess Publishing Co., Minneapolis, 1962.

\section{Acknowledgement}

Thanks are due F. S. Farmer, K. L. Kushman, L. M. Rawls, C. A. Keisler, Jr., and J. F. Hales for assistance in collecting data.

The authors' address:

Department of Entomology, North Carolina State University, Raleigh, N. C., 27607, USA. 